\title{
Assessment of vitamin D levels in patients with acute coronary syndrome
}

\author{
Hakki Simsek and Naci Babat* \\ Yuzuncu Yil University, Faculty of Medicine, Cardiology Department, Van, Turkey
}

\begin{abstract}
In recent studies, vitamin $\mathrm{D}$ is claimed to have positive effects for acute coronary syndrome (ACS) by decreasing states that are accepted as important risk factors for ACS development such as endothelial damage, high blood pressure, insulin resistance, diabetes development and vascular inflammation.

We have investigated the relation between ACS and plasma vitamin D levels in this study.

The study was conducted with a total number of 90 patients diagnosed with ACS and 50 individuals with normal coronary artery angiography. No significantly different plasma vitamin D levels of control group was detected compared to the patients with ACS (Mean=15.2 \pm 4.8 versus $15.3 \pm 6.3 \mathrm{ng} / \mathrm{ml}, \mathrm{p}>0.05$ ). Significant difference related to smoking prevalence was detected between the two groups $(52.8 \%$ versus $20 \%, \mathrm{p}<0.01)$.

We have concluded that Vitamin D insufficiency does not increase the risk for development of ACS significantly, after the corrections related to blood cholesterol elevation, smoking, diabetes, high blood pressure, family history. According to these results, there was no association between the plasma level of vitamin D and the risk of development of ACS.
\end{abstract}

Key Words: Atherosclerosis, acute coronary syndrome, vitamin D

\section{Introduction}

Acute coronary syndrome (ACS) is the most common cause of mortality and morbidity all over the world. Mortality and morbidity would be affected positively by clear definition of the risk factors for ACS, early and accurate diagnosis, and optimal treatment $(1,2)$. To evaluate the risk factor of ACS, in addition to classical risk factors several biochemical indicators may be used $(3,4)$. Vitamin $\mathrm{D}$ is a hormone which has multiple effects throughout the body. In addition to its classical effects on the musculoskeletal system, it regulates hormone secretion, immune functions and cell proliferation and differentiation. In epidemiological studies, it has been shown that Vitamin D levels are related to many diseases such as carcinomas, hypertension and cardiovascular diseases $(5,6)$.

In previous studies, conflicting outcomes have been reported with regard to the vitamin D levels in ACS. In this study, we aimed to investigate the correlation between vitamin D level and ACS.

\section{Materials and methods}

Ninety patients who were diagnosed ACS and performed coronary angiography (CAG), and fifty patients as control group with normal coronary anatomy in CAG were included in the study. No difference was detected between the study and control groups with regard to gender distribution and age parameters. No systemic disease was present in the participants.

Individuals of control group didn't have cardiovascular and systemic diseases. Pregnant or lactating patients and those with an immobility lasting more than a week or recent drug intake that affects vitamin $\mathrm{D}$ and calcium metabolism were excluded.

Patient data (history, risk factors, physical examination, laboratory findings and ECG findings) were recorded. Blood samples were collected from patients who were admitted with chest pain and were suspected to have ACS in order to check vitamin $\mathrm{D}$ levels and other various biochemical parameters within 24 hours after hospitalization. 25-hydroxyvitamin level was measured via an electrochemical luminescence technology using Cobas e601 module (Roche Diagnostics, Mannheim, Germany). Patient samples were kept at $2-8^{\circ} \mathrm{C}$ and were transferred to laboratory on Saturdays, Mondays and Wednesdays.

Normal value for 25-hydroxyvitamin $\mathrm{D}$ was accepted as $>10 \mathrm{ng} / \mathrm{ml}$. Therefore serum levels $<10 \mathrm{ng} / \mathrm{ml}$ were evaluated as hypovitaminosis $\mathrm{D}$. the patients 
were classified into 3 groups according to their 25hydroxyvitamin D levels. Patients with sufficient vitamin $\mathrm{D}$ had a level of $>20 \mathrm{ng} / \mathrm{dl} 25-$ hydroxyvitamin D. Patients with insufficient vitamin $\mathrm{D}$ had a level of 10-20 ng/dl 25-hydroxyvitamin. Patients with vitamin D deficiency had a 25hydroxyvitamin D level $<10 \mathrm{ng} / \mathrm{ml}$.

Study protocol was approved by the ethical committee of Yuzuncu Y1l University Medical Faculty. Written informed consents of all the participants were obtained.

Statistical analysis: Descriptive statistics were mean, standard deviation, minimal and maximal values for continuous variables, and numbers and percentages for categorical variables. Pearson correlation coefficients were measured separately for each group in order to determine the correlation between these variables. Chi-square test was used in order to determine the correlation between the groups and categorical variables, statistical significance level was accepted as 5\% and SPSS 16.0 program package was used for statistical analyses.

\section{Results}

Study group included 90 patients with acute coronary syndrome (group A) and 50 healthy individuals as control group (group B). The clinical and demographic characteristics of the groups are shown in Table 1, and laboratory findings are shown in Table 2.

No significant difference was observed between the groups with regard to hypertension and DM prevalence. Smoking prevalence was significantly different between the groups $(52.8 \%$ vs $20 \%$, $\mathrm{p}<0.01)$. None of the participants has taken vitamin $\mathrm{D}$ or calcium supplements within the last 3 months. In the ACS group; vitamin D level was below 10 $\mathrm{ng} / \mathrm{ml}$ in 9 patients $(10 \%)$, between 10 and $20 \mathrm{ng} / \mathrm{ml}$ in $66(74 \%)$, and over $20 \mathrm{ng} / \mathrm{ml}$ in $15(16 \%)$. In the control group, vitamin D level was below $10 \mathrm{ng} / \mathrm{ml}$ in 7 patients (14\%), between 10 and $20 \mathrm{ng} / \mathrm{ml}$ in 35 $(70 \%)$, and over $20 \mathrm{ng} / \mathrm{ml}$ in $8(16 \%)$. No significant difference was obtained between the groups with regard to hypovitaminosis D prevalence $(\mathrm{p}>0.05)$.

Patients with normal serum 25-hydroxyvitamin D levels were younger and had lower fasting blood glucose levels, although it is not significant.

Mean serum 25-hydroxyvitamin D level among smokers $(52.8 \%)$ of the study group was $14.6 \pm 7.8$ $\mathrm{ng} / \mathrm{ml}$, and was $15.3 \pm 10 \mathrm{ng} / \mathrm{ml}$ among non-smokers $(47.2 \%)$. The difference was not statistically significant $(\mathrm{p}>0.05)$.

\section{Discussion}

The risk factors should primarily be taken under control in order to reduce the mortality and morbidity rates related to coronary artery disease which is the most common cause of deaths worldwide. Vitamin D is a hormone precursor and a good indicator in the cardiovascular. On the other hand 1.25Dihydroxyvitamin D, is a mature hormone that plays role in mineral ion regulation (7).

The major source of vitamin $\mathrm{D}$ is cutaneous synthesis. Vitamin D synthesis in the skin depends on several variables such as skin pigmentation, latitude, season, age, skin protector usage, and local weather (8). Vitamin D is absorbed through the intestines during the digestion of both vegetative and zoic nutrients (7).

Vitamin D gets involved into the circulation and is converted to 25-hydroxyvitamin D in the liver. Serum 25-hydroxyvitamin D measurement is the most common test since it is the major storage form of vitamin D. Its half-life is approximately 2-3 weeks (9).

Table 1. Risk factors for CAD and resume features the working group-1

\begin{tabular}{lccc}
\hline & $\begin{array}{c}\text { Group A } \\
\text { (Acute coronary syndrome, n:90) }\end{array}$ & $\begin{array}{c}\text { Group B } \\
\text { (Control, n:50) }\end{array}$ & p value \\
\hline Hypertension & $29(32.2) \%$ & $15(30 \%)$ & $>0.05$ \\
Cigarette & $45(50 \%)$ & $10(20 \%)$ & $<0.01$ \\
Diabetes mellitus & $18(20 \%)$ & $11(22 \%)$ & $>0.05$ \\
Hyperlipidemia & $39(43.3 \%)$ & $20(40 \%)$ & $>0.05$ \\
Systolic BP (mmHg) & $125 \pm 25$ & $127 \pm 17(60-210)$ & $>0.05$ \\
Diastolic BP (mmHg) & $75 \pm 14$ & $72 \pm 15$ & $>0.05$ \\
Age & $55 \pm 25$ & $45 \pm 30$ & $>0.05$ \\
Sex (male/female) & $58 / 32$ & $33 / 17$ & $>0.05$ \\
\hline
\end{tabular}

BP: Blood pressure, $\mathrm{p}$ value; The statistical significance of the differences between men and women is the physical examination features. 
Table 2. Laboratory features of the working group

\begin{tabular}{|c|c|c|c|}
\hline & $\begin{array}{c}\text { Group A } \\
\text { (Acute coronary } \\
\text { syndrome) } \\
(n=90)\end{array}$ & $\begin{array}{c}\text { Group B } \\
(\text { Control) } \\
(n=50)\end{array}$ & $\mathrm{p}$ value \\
\hline Vitamin-D (ng/ml) & $\begin{array}{c}15.2 \pm 4.8 \\
(9-19)\end{array}$ & $\begin{array}{c}15.3 \pm 6.3 \\
(9-19)\end{array}$ & $>0.05$ \\
\hline Hemoglobin (mg/dl) & $\begin{array}{c}14.1 \pm 1.7 \\
(9-19)\end{array}$ & $\begin{array}{l}14.0 \pm 1.5 \\
(5.6-20)\end{array}$ & $>0.05$ \\
\hline Hematocrit (mg/dl) & $\begin{array}{c}43 \pm 5 \\
(20-53)\end{array}$ & $\begin{array}{c}43 \pm 4 \\
(15-63)\end{array}$ & $>0.05$ \\
\hline Creatinine $(\mathrm{mg} / \mathrm{dl})$ & $\begin{array}{c}1.0 \pm 0.9 \\
(0.35-5.9)\end{array}$ & $\begin{array}{c}0.9 \pm 0.5 \\
(0.40-2.5)\end{array}$ & $>0.05$ \\
\hline Glucose (mg/dl) & $\begin{array}{l}139 \pm 82 \\
(60-432)\end{array}$ & $\begin{array}{l}118 \pm 46 \\
(43-559)\end{array}$ & $>0.05$ \\
\hline Total cholesterol (mg/dl) & $\begin{array}{l}200 \pm 50 \\
(92-359)\end{array}$ & $\begin{array}{l}190 \pm 46 \\
(77-407)\end{array}$ & $>0.05$ \\
\hline LDL- cholesterol (mg/dl) & $\begin{array}{l}108 \pm 30 \\
(47-280)\end{array}$ & $\begin{array}{l}111 \pm 26 \\
(23-317)\end{array}$ & $>0.05$ \\
\hline HDL- cholesterol (mg/dl) & $\begin{array}{l}38 \pm 12 \\
(17-79)\end{array}$ & $\begin{array}{l}41 \pm 12 \\
(6-77)\end{array}$ & $>0.05$ \\
\hline Triglyceride (mg/dl) & $\begin{array}{l}125 \pm 59 \\
(36-496)\end{array}$ & $\begin{array}{l}179 \pm 82 \\
(22-647)\end{array}$ & $>0.05$ \\
\hline $\mathrm{CK} \mathrm{MB}(\mathrm{u} / \mathrm{L})$ & $\begin{array}{l}70 \pm 70 \\
(9-625)\end{array}$ & $\begin{array}{c}24 \pm 9 \\
(9-814)\end{array}$ & $>0.05$ \\
\hline Troponin & $\begin{array}{l}4.7 \pm 6.4 \\
(11-821)\end{array}$ & $\begin{array}{c}0.03 \pm 0.09 \\
(9-1031)\end{array}$ & $>0.05$ \\
\hline $\mathrm{CRP}(\mathrm{mg} / \mathrm{L})$ & $\begin{array}{l}32 \pm 42 \\
(5-150)\end{array}$ & $\begin{array}{c}7 \pm 5 \\
(3-15)\end{array}$ & $>0.05$ \\
\hline $\mathrm{Ca}(\mathrm{mg} / \mathrm{dl})$ & $\begin{array}{l}8.7 \pm 1.3 \\
(7.2-10)\end{array}$ & $\begin{array}{l}8.7 \pm 1.6 \\
(7.3-9.7)\end{array}$ & $>0.05$ \\
\hline $\mathrm{P}(\mathrm{mmol} / \mathrm{L})$ & $\begin{array}{l}3.5 \pm 0.8 \\
(3.2-4.0) \\
\end{array}$ & $\begin{array}{l}3.2 \pm 0.6 \\
(3.0-3.9) \\
\end{array}$ & $>0.05$ \\
\hline
\end{tabular}

$\mathrm{p}$ value; women and men is the statistical value of the difference between laboratory characteristics. LDL: Lowdensity lipoprotein, the HDL: High-density lipoprotein, CK-MB: creatine kinase-MB fraction.

Recently, the normal level for 25-hydroxyvitamin $\mathrm{D}$ is accepted as $20-76 \mathrm{ng} / \mathrm{ml}(75-190 \mathrm{nmol} / \mathrm{l})(8)$.

Major risk factors for vitamin D deficiency are age, obesity, dark skin color, insufficient sun exposure and fat malabsorption.

In this study, no significant difference was observed between the groups with regard to the vitamin D levels.

Due to the rather lower attitude degree and sunny weather of the region this study was conducted, it is not surprising that the vitamin $\mathrm{D}$ deficiency prevalence is not low. Our study was conducted in the winter and spring. None of our participants has used sun protector vitamin $\mathrm{D}$ or calcium nutrient supports. Furthermore, although the temperature is low in winter and spring, in the region this study was conducted, most of the days are sunny. The cloth type of the women (turbans) may be another factor avoiding sufficient sun exposure; we did not detect any statistical difference between men and women with regard to serum 25-hydroxyvitamin D levels.

Obesity may result in lower levels of 25hydroxyvitamin $\mathrm{D}$ in the serum. The reason for that may be less exercise and sun exposure, and catabolization of 25-hydroxyvitamin $\mathrm{D}$ in fat tissues $(8,10)$. In this study, lower serum 25-hydroxyvitamin D levels were observed among obese patients although it is not significant. The reason for that may 
be the low number of obese patients. The BMIs of our patients which are close to normal may have contributed to the low levels of vitamin D.

Air pollution is one of the factor that reduce the vitamin $\mathrm{D}$ synthesis in the skin. Low degree of air pollution in the region of Van may have positively affected the vitamin D synthesis.

There are studies indicating major role of vitamin $\mathrm{D}$ in the etiology of diabetes mellitus, hypertension, cancer and cardiovascular diseases (10-13). Likewise, many studies have reported that the risk of coronary artery diseases and myocardial infarction is higher among people with vitamin D deficiency $(11,14,15)$.

Vitamin D deficiency may be contributing to the cardiovascular diseases through renin expression, cardiomyocyte and smooth muscle cell proliferation, secondary hyperparathyroidism or inflammation. Vitamin D has several anti-hypertrophic effects, suppression effects via the renin-angiotensin system, modulator effects on contractility and regulator effects on extracellular matrix turnover. Furthermore, it prevents vascular calcification, improves endothelial function and has anti-atherosclerotic effects. It is also a coronary artery disease risk factor modulator (16). Despite these data, it is not clear if its deficiency has a direct or indirect role in cardiovascular diseases. In our study, we did not detect any vitamin $\mathrm{D}$ alteration in patients with ACS as well.

Although the significance of vitamin D deficiency in coronary artery diseases has been proven by many observational studies, the effect of vitamin D supportion on coronary artery diseases is not clear. In the large study investigating the effects of vitamin D support on cardiovascular events, no significance was obtained (16).

Our data have demonstrated higher systolic blood pressure values in patients with hypovitaminosis $\mathrm{D}$ $(<10 \mathrm{ng} / \mathrm{ml})$ which is also consistent with the results obtained in previous studies (17). Reduced renin activity caused by increased intracellular calcium levels, renin promotor gene suppression and impaired vascular smooth muscle sensitivity are the possible mechanisms in the blood pressure regulation of vitamin D (18).

No correlation was detected between hypovitaminosis $\mathrm{D}$ in patients with acute coronary syndrome and inhospital mortality. This may be due to our small sample size.

Major limitations of our study are insufficient patient count, that we could consider the patients in winter and spring only. Furthermore, we did not evaluate daily vitamin $\mathrm{D}$ and calcium intake of the patients in the study and control groups.

As a conclusion, no significant vitamin $\mathrm{D}$ deficiency was detected in patients with acute coronary syndrome diagnosis. No correlation was detected between vitamin D levels and mortality. Prospective studies with larger samples sizes are needed in order to investigate the vitamin $\mathrm{D}$ deficiency research and the benefits of its treatment.

Disclosure: The authors report no conflicts of interest in this work.

\section{References}

1. Solinas L, Raucci R, Terrazzino S, et al. Prevalence, clinical characteristics, resource utilization and outcome of patients with acute chest pain in the emergency department. A multicenter, prospective, observational study in north-eastern Italy. Italy Heart J 2003; 4: 318-324.

2. T.C. Ministry of Health, General Directorate of Primary Health Care Services, Ankara, Turkey Cardiovascular Disease Prevention and Control Program; Strategic Plan and Action Plan for Risk Factors, publication no: 812, date: 2010.

3. Weiss R, Dziura J, Burgert TS, et al. Obesity and the metabolic syndrome in children and adolescents. N Engl J Med 2004; 350: 23622374.

4. Ninomiya JK, L'Italien G, Criqui $\mathrm{MH}$, et al. Association of the metabolic syndrome with history of myocardial infarction and stroke in the Third National Health and Nutrition Examination Survey. Circulation 2004; 109: 4246.

5. Holick MF. Vitamin D: importance in the prevention of cancers, type 1 diabetes, heart disease, and osteoporosis. Am J Clin Nutr 2004; 79: 362371.

6. Holick MF. Sunlight and vitamin D for bone health and prevention of autoimmune diseases, cancers, and cardiovascular disease. Am J Clin Nutr 2004; 80: 1678-1688.

7. Gordon DJ, Probstfield JL, Garrison RJ, et al. High-density lipoprotein cholesterol and cardiovascular disease. Four prospective American studies. Circulation 1989; 79: 8-15.

8. Criqui MH, Wallace RB, Heiss $G$, et al. Cigarette smoking and plasma high-density lipoprotein cholesterol. The Lipid Research Clinics Program Prevalence Study. Circulation 1980; 62: IV70-IV76.

9. Wood PD, Stefanick ML, Williams PT, Haskell WL. The effects on plasma lipoproteins of a prudent weight-reducing diet, with or without exercise, in overweight men and women. N Engl J Med 1991; 325: 461-466.

10. Campeau L. Letter: Grading of angina pectoris. Circulation 1976; 54: 522-523.

11. Assmann G, Schulte H. Relation of high-density lipoprotein cholesterol and triglycerides to incidence of atherosclerotic coronary artery disease (the PROCAM experience). Prospective Cardiovascular

\footnotetext{
East J Med Volume:21, Number:4, October-December/2016
} 
Münster study. Am J Cardiol 1992; 70: 733-737.

12. Demirci C, Ozbakkaloğlu M, Yildirim A, Cakmak T, Yavuzgil C. Plasma Homocysteine Levels in Patients with Acute Coronary Syndrome. SSK Tepecik hospital journal 2003; 13: 91-96.

13. Akbulut M, Ozkan Y. Unstable Relationship between C-Reactive Protein (CRP) Levels and Coronary Arterial Involvement in Patients with Angina Pectoris. Frrat University Journal of Health Sciences 2000; 14: 291-294.

14. Fox KA. Coronary disease. Acute coronary syndromes: presentation--clinical spectrum and management. Heart 2000; 84: 93-100.
15. Braunwald E. Unstable angina. A classification. Circulation 1989; 80: 410-414.

16. Genest JJ Jr, Martin-Munley SS, McNamara JR, et al. Familial lipoprotein disorders in patients with premature coronary artery disease. Circulation 1992; 85: 2025-2033.

17. Hasdai D, Porter A, Rosengren A, et al. Effect of gender on outcomes of acute coronary syndromes. Am J Cardiol 2003; 91: 1466-1469.

18. McSweeney JC, Cody M, O'Sullivan P, et al. Women's early warning symptoms of acute myocardial infarction. irculation 2003; 108: 2619 2623. 